\title{
STUDY OF LIPID PROFILE TRENDS IN WOMEN OF PREGNANCY INDUCED HYPERTENSION CASES IN A RURAL SETUP.
}

\author{
Amandeep Singh Kaloti, Charanjeet Kaur, R. K. Goel, S. Jha,
}

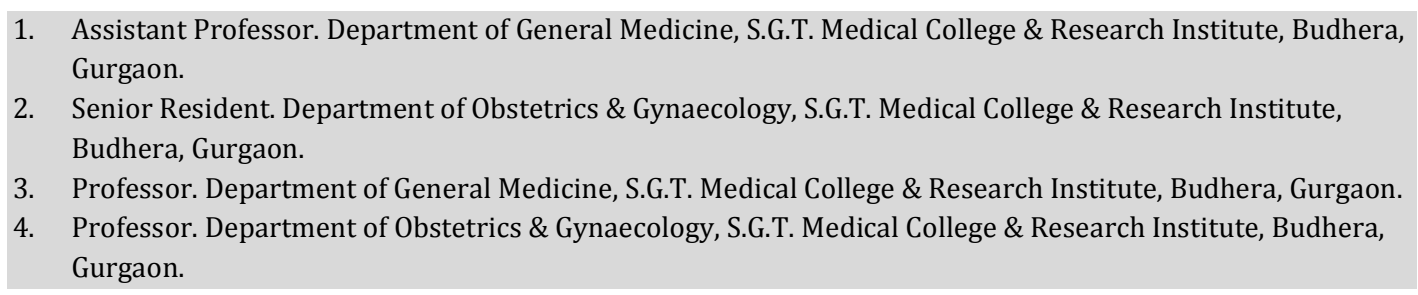

\section{CORRESPONDING AUTHOR:}

Amandeep Singh Kaloti,

S.G.T Medical college and research institute,

Budhera, Gurgaon.

E-mail: amansaini1231@rediffmail.com

ABSTRACT: OBJECTIVE: Elevated plasma lipid levels are believed to be probable cause of endothelial cell dysfunction. We planned to measure the changes in the lipid levels in patients of PIH (pregnancy induced hypertension) and compare it with that of normotensive pregnant females. MATERIALS \& METHODS: We studied 804 pregnant women. 624 patients studied were of PIH and 180 patients were healthy pregnant women. Lipid levels were estimated in these pregnant women. RESULTS: We found a significant rise in the serum lipid levels in the PIH patients group as compared to normotensive pregnant females, which were highly significant $(\mathrm{P}<0.001)$ except changes in LDL $(\mathrm{P}>0.05)$ and total cholesterol. Amongst the different lipoprotein ratios, TC: HDL, LDL: HDL, TG: HDL, and HDL: VLDL ratios were found highly significant $(\mathrm{p}<0.001)$ in PIH patients group. CONCLUSION: It is essential that blood lipid concentrations be estimated in pregnant women during antenatal care since it could be useful in early diagnosis and prevention of obstetric complications such as PIH.

INTRODUCTION: Pregnancy induced hypertension is recognized since ancient times. It has been described in reviews of Thiagarajha and Chesley ${ }^{1}$.

Hypertension after 20 weeks of pregnancy in a woman with edema and proteinuria without previous history of hypertension is called pregnancy induced hypertension (PIH). When associated with proteinuria, the disorder is termed pre - eclamptic eclampsia/ toxemia and when present without protein in the urine, it is called transient hypertension or gestational hypertension ${ }^{2}$. Raised blood pressure is present in 5\% of entire pregnancies, in $10 \%$ of primiparous women and $20-25 \%$ of women with pervious history of chronic hypertension. It is the major cause of fetomaternal morbidity and mortality 3 .

When blood pressure rises in pregnancy with significant protein in the urine, it is called pre- eclampsia. It may occur from 20 weeks of pregnancy. It can also occur upto 6 weeks post partum. Delivery of the placenta is the ultimate treatment. It may affect both fetal and mother survival4.

Eclampsia is a dangerous complication of pregnancy with a sudden onset and has the features of developing tonic - colonic seizures in a patient who has pre - eclampsia. With increasing age, the risk of developing PIH increases ${ }^{5}$. 
Lipoprotein levels increase during pregnancy, but in PIH they increase two to three times more (6-8). Changes in lipoproteins in essential hypertension are documented ${ }^{9}$. Abnormal lipoprotein levels are responsible for damage to the endothelium which leads to high blood pressure and proteinuria; which are important signs of $\mathrm{PIH}^{10}$.

Change in lipoproteins cause atherosclerosis, damage to endothelium and other heart diseases. The major sign of PIH is hypertension, suggesting that it is due to vasospastic events in placenta, uterus and brain (11).

Abnormal lipid metabolism has a basic role in the pathogenesis of the disease ${ }^{(12) . E n d o t h e l i a l ~}$ dysfunction can explain the protein in the urine (13). Abnormal lipid metabolism is responsible for the endothelial dysfunction (15), and it was proposed that small, dense LDL may add to endothelial dysfunction in pre - eclampsia (16-17). Triglyceride rich lipoproteins may also activate endothelial dysfunction (18) and atherothrombosis(19) . In toxemia of pregnancy, serum triglyceride concentration increases much more notably. In pregnancy, the increased level of estrogen causes increased hepatic biosynthesis of endogenous triglycerides through VLDL (13). This process is modulated by hyperinsulinism that starts in pregnancy (14). All the above mentioned interactions along with increased endothelial triglyceride accumulation may result in endothelial cell damage in pregnancy (17). In PIH, the triglycerides are likely to be accumulated in vessels like uterine spiral arteries and contribute to endothelial damage by generating small, dense LDL particles. Women with PIH are more likely to develop overweight, dyslipidemia (16-20), insulin resistance (21-22) and endothelial dysfunction (23), which are independent risk factors for cardiovascular disease (24-25).

Lipoproteins are classified into: - HDL, LDL, VLDL and chylomicrons.

MATERIALS AND METHODS: This cross sectional /analytical study was conducted in the tertiary referral health care facility of Budhera, Gurgaon, viz, SGT Medical College and Research centre, Budhera, Gurgaon, India. The analytical work was done in SGT Medical College and Research centre, Budhera, Gurgaon.

Study population included pregnant women with $\mathrm{PIH}$ as cases and normotensive pregnant women at gestational age of 20 weeks or more as controls.

The study was undertaken on 804 pregnant women. Among which, 624 were pregnant women with PIH admitted to Gynaecology and Obstetrics department or undergoing prenatal care at tertiary referral health care facility, who were randomly selected and screened for PIH at their prenatal visits, on labor and delivery. From the same health facility, 180 healthy pregnant women without history of hypertension, diabetes mellitus, renal or cardiovascular disease were randomly selected as age, weight, BMI gestational period and socio - economic matched control group for comparison.

After explaining aim and objectives, informed consent was taken from each subject for participation in this study.

Ethical approval for the study was obtained from Institutional Ethical Research Board at SGT Medical College and Research Institute, Budhera, Gurgaon.

Biochemical analysis of lipoprotein included total cholesterol, HDL, LDL , VLDL , triglycerides.

Serum lipids were analysed enzymatically by using Semi Auto Chemistry Analyser Microlab 200. Serum total cholesterol and triglycerides were measured by using enzymatic method of Elitech digi kits of France. Serum HDL was measured by using kits of Merk Diagnostics.

Serum LDL was calculated by Frederickson - Friedawld's formula, according to which LDL = TC - HDL - VLDL. 
VLDL was calculated as $1 / 5$ of triglycerides. Students t test was used to evaluate mean differences in maternal serum lipids concentration between patient and control subjects. Significance among the mean of groups was expressed in terms of "p" value. $95 \%$ confidence internal $\mathrm{p}<0.05$ was considered significant.

RESULTS: Table 1 compares the mean (+-SEM) lipoprotein concentration among the study groups. Statistically highly significant $(\mathrm{p}<0.001)$ differences were noted in most of maternal serum lipid and lipoprotein concentrations in the patient group of PIH, except changes in LDL $(\mathrm{P}>0.05)$, and total cholesterol. Amongst the different lipoprotein ratio, TC: HDL , LDL : HDL , TG :HDL and HDL :VLDL ratios were found highly significant $(\mathrm{P}<0.001)$ in the PIH patient group.

Table 1:- blood lipids in Normal Pregnancy and patients for pregnancy induced hypertension.

\begin{tabular}{|c|c|c|c|c|}
\hline $\begin{array}{l}\text { Lipoprotein } \\
\text { (mg/dl) }\end{array}$ & $\begin{array}{l}\text { PIH } \\
\text { Mean } \\
\pm \text { SEM }\end{array}$ & $\begin{array}{l}\text { Control } \\
\text { Mean } \\
\pm \text { SEM }\end{array}$ & $\begin{array}{l}\text { \% } \\
\text { Change }\end{array}$ & $\begin{array}{l}\mathbf{P} \\
\text { Value }\end{array}$ \\
\hline Total Cholesterol & $\begin{array}{l}213.25 \\
\pm 3.14\end{array}$ & $\begin{array}{l}188.23 \\
\pm 4.6\end{array}$ & 5.5 & NS \\
\hline $\begin{array}{l}\text { HDL - Cholesterol } \\
(\mathrm{mg} / \mathrm{dl})\end{array}$ & $\begin{array}{l}43.45 \\
\pm 0.58\end{array}$ & $\begin{array}{l}52.20 \\
\pm 1.14\end{array}$ & 16.8 & 0.001 \\
\hline $\begin{array}{l}\text { LDL- Cholesterol } \\
(\mathrm{mg} / \mathrm{dl})\end{array}$ & $\begin{array}{l}111.15 \\
\pm 2.91 \\
\end{array}$ & $\begin{array}{l}93.42 \\
\pm 4.07\end{array}$ & 3.5 & NS \\
\hline $\begin{array}{l}\text { VLDL-Cholesterol } \\
(\mathrm{mg} / \mathrm{dl})\end{array}$ & $\begin{array}{l}58.74 \\
\pm 1.44\end{array}$ & $\begin{array}{l}42.22 \\
\pm 1.46\end{array}$ & 39.1 & 0.001 \\
\hline $\begin{array}{l}\text { Triglyceride } \\
(\mathrm{mg} / \mathrm{dl})\end{array}$ & $\begin{array}{l}294.25 \\
\pm 7.24 \\
\end{array}$ & $\begin{array}{l}212.30 \\
\pm 7.28 \\
\end{array}$ & 38.36 & 0.001 \\
\hline
\end{tabular}

Differences in the mean and standard error of mean in blood lipids of patient and control subjects is represented in table 1.

Women who developed hypertension after 20 wks of gestation had 5.45\%, 3.5\% 39\% , and $38.6 \%$ higher concentration of total cholesterol, LDL, VLDL and triglycerides respectively than control subjects.

A significant decrease of $16.76 \%$ was noted in HDL in patient group.

Comparison of lipoprotein ratio among patient and control groups is given in table 2 .

Table 2:- Comparison of lipoprotein ratio in normal and pregnancy induced hypertension.

\begin{tabular}{|l|l|l|l|l|}
\hline Parameters & PIH & Control & $\%$ & P \\
& Mean \pm SEM & Mean \pm SEM & change & Value \\
\hline
\end{tabular}




\begin{tabular}{|l|l|l|l|l|}
\hline TC : HDL ratio & $5.12 \pm 0.09$ & $3.74 \pm 0.11$ & 32.29 & 0.001 \\
\hline LDL : HDL ratio & $2.66 \pm 0.07$ & $1.86 \pm 0.09$ & 29.76 & 0.001 \\
\hline TG : HDL ratio & $7.24 \pm 0.22$ & $4.35 \pm 0.19$ & 66.44 & 0.001 \\
\hline HDL : VLDL ratio & $0.87 \pm 0.02$ & $1.36 \pm 0.06$ & 38.23 & 0.001 \\
\hline
\end{tabular}

Total Cholesterol: HDL ratio, LDL : HDL ratio and TG:HDL ratios were higher in PIH group and were found highly significant $(\mathrm{P}<0.001)$

DISCUSSION: Elevated plasma lipid levels are believed to be the probable cause of endothelial cell dysfunction. In the endothelial cell, oxidative stress is stimulated by linoleic acid. During pregnancy serum lipoprotein levels increase considerably and is two times higher in PIH. Alterations that take place during pregnancy include insulin resistance, hyper - lipidaemia and up - regulation of inflammatory markers (29-31). The increase of serum lipids through pregnancy in general and during PIH in particular are described in a number of studies. Worldwide, diverse studies (29,36-38) have reported elevated lipid levels in PIH patients. Our study also showed that rise in serum triglycerides was statistically significant $(\mathrm{p}<0.001)$ in PIH patients when compared to women with normal pregnancy. The major modulator of this hypertriglyceridemia is estrogen as pregnancy is linked with hyperestrogenemia. Hypertriglyceridemia may be linked to hypercoagulability(40). In the present study cholesterol concentration increased in patients of PIH but no significant changes in total cholesterol were observed. These are consistent with findings reported in other studies (29,35). Some other studies have found considerable rise in serum cholesterol in PIH. The finding in our study of $16.8 \%$ lower value of HDL $-\mathrm{C}$ in PIH patients over patients of normal pregnancy is consistent with the study on Finnish and Peruvian population (43-44). Statistically the variation was highly significant, $(\mathrm{p}<0.001)$.

Estrogen is responsible for induction of triglycerides and HDL and inhibition of serum LDL and estrogen level falls in PIH (45).Low levels of HDL in PIH is not only because of hypoestrogenemia but also due to insulin resistance ${ }^{(43)}$.

In our study, serum VLDL levels rose significantly $(\mathrm{p}<0.001)$ in the patient PIH group which may be due to hypertriglyceridemia leading to increased entry of VLDL that carries the endogenous triglycerides into the circulation. Some researchers (46) have shown serum VLDL levels may rise upto 2.5 folds at term over pre-pregnancy levels. VLDL levels further elevates in PIH as found in the present study in validation with those of other researchers $(29,38)$, due to increased VLDL which accumulates over maternal vascular endothelium, mainly those of uterine and renal vessels. VLDL may cause injury to the endothelium (47). Similar results are shown by another study (46) and one study from China (49).

We have also calculated the ratios between lipids like LDL: HDL, TC: HDL, TG : HDL, HDL: VLDL for patients and control groups. There was great increase in LDL: HDL, TC: HDL, TG: HDL and HDL: VLDL ratios in PIH. This is consistent with other studies (48). Dyslipidemia mediates activation of endothelial cells to placental derived factors which can be considered as probable contributors for the pathogenesis of PIH (50).

Our results are in comparison with findings from few exiting prospective studies, case control studies (29,41), and many prospective cohort studies (51-52) of maternal fasting / non 
fasting serum lipid and lipoprotein concentrations in PIH and normotensive pregnancies. In these PIH patients, decrease in HDL regardless of elevation in other lipid components is a probable threat for atherosclerosis (53). A similar study has been done by Gratacos E et al.

CONCLUSION: Women who developed hypertension after 20wks of gestation had 5.45\%, 3.5\%, $39 \%$, to $38.6 \%$ higher concentration of total cholesterol, LDL, VLDL and triglyceride levels respectively, than control subjects. A significant decrease of $16.76 \%$ was noted in HDL levels of PIH group.

Total cholesterol: HDL, LDL: HDL and TG: HDL ratios were higher $(32.3 \%, 29.8 \%$ and $66.4 \%$ respectively) among women with PIH and were found to be statistically significant $(\mathrm{P}<0.001)$ as compared to normotensive women.

In conclusion, the results of our study show abnormal lipid metabolism, predominantly low HDL and high triglyceride concentration which may promote vascular dysfunction and oxidative stress seen in PIH. It is therefore essential that serum lipid concentration should be estimated in all pregnant women during antenatal care, since it could be useful in the early diagnosis and prevention of obstetric complications such as PIH.

\section{REFERENCES:}

1. Chesley LC. History and epidemiology of pre-eclampsia - eclampsia. Clin Obstet \& Gynecol 1984;27:801-20.

2. World Health Organization. The World Health Report 1998: life in the 21 $1^{\text {st }}$ century: a vision for all. Geneva: WHO 1998, p.97.

3. Ghosh MK. Maternal mortality: a global perspective. J Reprod Med 2001; 46:427-33.

4. Drife J0, Magowan (eds). Clinical Obstetrics and Gynaecology, chapter 39, pp 367-370. ISBN 0-7020-1775-2. Published by Elsevier Health Sciences, 2004.

5. Zhang J. Partner change, birth interval and risk of pre - eclampsia: a paradoxical triangle. Paediatr Perinat Epidemiol. 2007; 21 Suppl 1:31-5.

6. Uotila JT, Tuimala RJ, Aarnio TM. Findings on lipid peroxidation and antioxidant function in hypertensive complication of pregnancy. Br. J. Obstet Gynecology, 1993;100:270-276.

7. Maseki M, Nishigaki l, Hagihara H, Tomoda Y, Yagi K. Lipid peroxide levels and lipid content of serum lipoprotein fractions of pregnant subjects with or without preeclampsia. Clin. Chim. Acta 1981;115:155-161.

8. Wickens D, Wilkins MH, Lunec J, Ball G, Dormandy TL. Free radical oxidation (peroxidation) products in normal and abnormal pregnancy. Ann. Clin. Biochem. 1981;18:158-162.

9. Jayanta De, Ananda K, Mukhopadhyay, Pradip K S. Study of serum lipid profile in pregnancy induced hypertension. Ind Jl of Clin Biochem. 2006; 21: 165-168.

10. Winkler K, Wetzka B, Hoffmann MM, Friedrich I, Kinner M, Manfred WB, Zahradnik H, Winfried M. Triglyceride-Rich Lipoproteins Are Associated with Hypertension in Preeclampsia. The J of Clin Endocrinol \& Metabol 2003; 88:1162-1166.

11. Dutta, D.C. Hypertensive disorders in pregnancy, In: Textbook of Obstetrics, Ed. Konar, H.L., $5^{\text {th }}$ edition, New Central Book Agency, Kolkata. 2001. p 234-55.

12. Robson, S.C. Hypertension and renal disease in pregnancy, In: Dewhurst's Textbook of Obstetrics and Gynecology for postgraduates, Ed. Edmonds, D.K., $6^{\text {th }}$ edition, Blackwell Science Ltd., New York. 1999; p 167-9. 
13. Dekker GA, Van Geijn HP. Endothelial dysfunction in pre-eclampsia. Part I: Primary prevention. Therapeutic perspectives. J Perinat Med. 1996;24:99-117.

14. Lorentzen B, Endresen MJ, Hovig T, Haug E, Henriksen T. Sera from pre-eclamptic women increases the content of triglycerides and reduces the release of prostacyclin in cultured endothelial calls. Thromb Res. 1991;63:363-372.

15. Zeiher AM, Drexler H, Wollschlager H, Just H. Modulation of coronary vasomotor tone in humans. Progressive endothelial dysfunction with different early stages of atherosclerosis. Circulation. 1991;83: 391-401.

16. Sattar N, Bendomir A, Berry C, Shepherd J, Greer IA, Packard CJ. Lipoprotein subfraction concentrations in pre-eclampsia: Pathogenic parallels to atherosclerosis. Obstet Gynecol. 1997;89:403-408.

17. Hubel CA, Lyall F, Weissfeld L, Gandley RE, Roberts JM. Small low-density lipoproteins and vascular cell adhesion molecule-1 are increased in association with hyperlipidemia in pre-eclampsia. Metabolism. 1998;47:1281-1288.

18. Kugiyama K, Doi H, Motoyama T, Soejima H, Misumi K, Kawano H, Nakagawa O, Yoshimura M, Ogawa H, Matsumura T, Sugiyama S, Nakano T, Nakajima K, Yasue H. Association of remnant lipoprotein levels with impairment of endothelium-dependent vasomotor function in human coronary arteries. Circulation 1998;97:2519-2526.

19. Mochizuki M, Takada Y, Urano T, Nagai N, Nakano T, Nakajima K, Takada A. The in vitro effects of chylomicron remnant and very low density lipoprotein remnant on platelet aggregation in blood obtained from healthy persons. Thromb Res. 1996;81:583-593.

20. Belo L, Caslake M, Gaffney D, Santos-Silva A, Pereira-Leite L, Quintanilha A, et al. Changes in LDL size and HDL concentration in normal and preeclamptic pregnancies. Atherosclerosis 2002; 162:425-32.

21. Kaaja R, Laivuori H, Laakso M, Tikkanen MJ, Ylikorkala O. Evidence of a state of increased insulin resistance in pre-eclampsia. Metabolism 1999;48:892-6.

22. Seely EW, Solomon CG. Insulin resistance and its potential role in pregnancy-induced hypertension. J Clin Endocrinol Metab 2003;88:2393-8.

23. Roberts JM. Endothelial dysfunction in pre-eclampsia. Semin Reprod Endocrinol 1998;16:5-5.

24. Isomaa B, Almgren P, Tuomi T, Forsen B, Lahti K, Nissen M, et al. Cardiovascular morbidity and mortality associated with the metabolic syndrome. Diabetes Care 2001;24:683-9.

25. Girman CJ, Rhodes T, Mercuri M, Pyorala K, Kjekshus J, Pedersen TR, et al. The Metabolic syndrome and risk of major coronary events in the Scandinavian Simvastatin Survival Study (4S) and the Air Force/Texas Coronary Atherosclerosis Prevention Study (AFCAPS/TexCAPS). Am J Cardiol 2004;93:136-41.

26. Mohanty S, Nayak N, Nanda NN, Pragna R. Serum Lipids and Malondialdehyde levels in primiparous patients with pregnancy induced hypertension. Ind J of Clin Biochem 2006;21:189-192.

27. Lorentzen B, Henriksen T. Plasma lipids and vascular dysfunction in pre-eclampsia. Semin Reprod Endocrinol 1998;16:33-39.

28. Rodie VA, Freeman DJ, Sattar N, Greer IA. Pre-eclampsia and cardiovascular disease: metabolic syndrome of pregnancy? Atherosclerosis 2004;175:189-202. 
29. Sattar N, Bendomir A, Berry C, Shepherd J, Greer IA, Packard CJ. Lipoprotein subfraction concentrations in pre-eclampsia: Pathogenic parallels to atherosclerosis. Obstet Gynecol 1997;89:403-8.

30. Redman CW, Sacks GP, Sargent IL. Pre-eclampsia: an excessive maternal inflammatory response to pregnancy. Am J Obstet Gynecol 1999;180:499-506.

31. Sattar N, Greer IA, Louden J, Lindsay G, McConnell M, Shepherd J, et al. Lipoprotein subfraction changes in normal pregnancy. J Clin Endocrinol Metab 1997;82:2483-91.

32. Geller SE, Ahmed S, Brown ML. International classification of diseases-9 $9^{\text {th }}$ revision coding for pre-eclampsia. How accurate is it? Am J. of Obstet. \& Gynecol. 2004;190:16291634.

33. Jennifer C, Dempsey, Michelle A, Williams, Wendy, Leisenring M. Maternal birth weight in relation to plasma lipid concentrations in early pregnancy. Am J. of Obstet. \& Gynecol. 2004;190:1359-1368.

34. Gratacos E. Lipid mediated endothelial dysfunction: A common factor to pre-eclampsia and chronic vascular disease. Eur. J. Obstet. Gynecol. Repord. Biol. 2000;92:63-66.

35. Cekmen MB, Erbagci AB, Balat A, Duman C, Maral H, Ergen K, Ozden M, Balat O, Kuskay S. Plasma lipid and lipoprotein concentrations in pregnancy induced hypertension. Clin Biochem. 2003;36:575-578.

36. Seely EW, Solomon CG. Insulin Resistance and its potential role in pregnancy induced hypertension. J. Clin. Endocrinol. Metab. 2003;88:2393-2398.

37. Forest JC, Girouard J, Masse J, Moutiquin JM, Kharfi A, Ness RB, Roberts JM, Giguere Y. Early occurance of metabolic syndrome after hypertension in pregnancy. Obstet. Gynecol. 2005;105:1373-1380.

38. Turpin CA, Ahenkorah L, Owiredu WKBA, Laing EF, Amidu N. The prevalence of the metabolic syndrome among Ghanaian pregnancy induced hypertension patients using the World health Organisation and the National Cholesterol Education Program III criteria. J. Med. Sci. 2008;8:443-451.

39. Glueck CJ, Fallat RW, Scheel D. Effects of estrogenic compounds on triglyceride kinetics. Metabolism, 1975;24:537-545.

40. Kokia E, Barkai G, Reichman B, Segal P, Goldman B, Mashiach S. Maternal serum lipid profile in pregnancies complicated by hypertensive disorders. J. Perinat. Med. 1990;18:473-78.

41. Hubel C, McLaughlin M, Evans R, Hauth B, Sims C, Roberts J: Fasting serum triglycerides, free fatty acids, and malondialdehyde are increased in Pre-eclampsia, are positively correlated, and disease within 48 hours post partum. Am J Obstet Gynecology 1996;174:975-982.

42. Franz H, Wendler D. A controlled study of maternal serum concentrations of lipoproteins in pregnancy- induced hypertension. Arch Gynecol Obstet 1992;252:81-86.

43. Kaaja R, Tikkanen MJ, Viinikka L, Ylikorkola O. Serum lipoproteins, insulin and urinary prostanoid metabolites in normal and hypertensive pregnant women. Obstet Gynecol 19958;5:353-6.

44. Ware JS, Sanchez SE, Zhang C, Laraburre G. Plasma lipid concentrations in preeclamptic and normotensive Peruvain women. Int J Gynecol Obstet 1999;67:147-55.

45. Dutta DC. Hypertensive disorders in pregnancy, In: Textbook of Obstetrics, Ed. Konar HL. $5^{\text {th }}$ edition, New Central Book Agency, Kolkata, 2001; p 234-55. 
46. Teichmann AT, Wieland H, Cremer P, Knlow G, Mehle U. Serum lipid and lipoprotein concentrations in pregnancy and at onset of labour in normal and complicated pregnancies caused by hypertensive gestosis and fetal growth retardation. Geburtshilfe Frauenheilkd 1988;48:134-9.

47. Arbogast BW, Leeper SC, Merrick RD, Olive KE, Taylor RN. Which plasma factors bring about disturbance of endothelial function in pre-eclampsia? Lancet 1994; 343 (8893):340-1.

48. Bayhan G, Kocyigit Y, Atamer A, Atamer Y, Akkus Z. Potential atherogenic roles of lipids, lipoprotein(a) and lipid peroxidation in pre-eclampsia. Gynecol Endocrinol. 2005; 21:16

49. Bai H, Liu X, Liu R, Liu Y, Li M, Liu B. Analysis of serum lipid and apolipoprotein levels in pregnancy-induced hypertension and normotensive pregnant women. Hua Xi Yi Ke Da Xue Xue Bao 2002; 33: 58-61.

50. Lorentsen B, Henrickson T. Plasma lipids and vascular dysfunction in pre-eclampsia. Semin Reprod Endocrinol 1998;33-39.

51. Belo L, Caslake M, Gaffney D, Santos- Silva A, Pereira-Leite L, Quintanilha A, Rebelo I: Changes in LDL size and HDL concentration in normal and preeclamptic pregnancies. Atherosclerosis 2002; 162:425-432.

52. Clausen T, Djurovic S, Henriksen T: Dyslipidemia in early second trimester is mainly a feature of women with early onset pre-eclampsia. Br J Obstet Gynecol 2001;108:10811087.

53. Streinberg D, Parthasarathy S, Carew TE, Khoo JD, Witztum JL. Beyond cholesterol. Modification of low density lipoprotein that increases its atherogenecity. N. Eng. J. Med. 1989; 320,915-924.

54. Gratacos E, Casals E, Sanllehy C, Cararach V, Alonso PL, Fortuny A: Variation in lipid levels during pregnancy in women with different types of hypertension. Acta Obstet Gynecol Scand 1996; 75:896-901. 